Archived version from NCDOCKS Institutional Repository http://libres.uncg.edu/ir/asu/

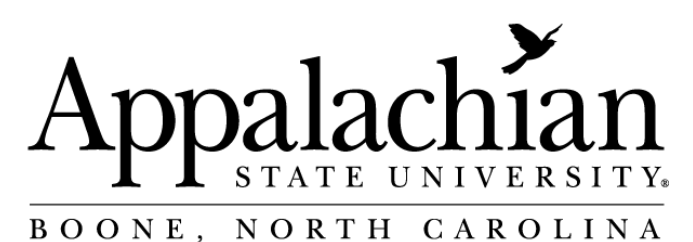

B O O N E, N O R T H C A R O L I N A

\title{
Using A Nursing History Web Site With Today's Nursing Students
}

\section{By: Paul Orkiszewski, Phoebe Pollitt, Andrea Leonard, and Susan Hayes Lane}

\begin{abstract}
Recognizing the importance of nursing history, an interdisciplinary team at Appalachian State University created a North Carolina Nursing History Web site (http://nursinghistory.appstate.edu/). The Web site can be used for teaching undergraduate and graduate nursing and other health professions students.
\end{abstract}

Orkiszewski, P., Pollitt, P.A., Leonard, A.A., \& Lane, S.H. (2015). Using a Nursing History Web Site With Today's Nursing Students. Nurse educator, 40 6, 31 2. Publisher version of record available at: https://journals.Iww.com/nurseeducatoronline/fulltext/2015/11000/

Using_a_Nursing_History_Web_Site_With_Today_s.14.aspx 


\section{Using a Nursing History Web Site With Today's Nursing Students}

Nurse Educator: November/December 2015 - Volume 40 - Issue 6 - p 312

doi: 10.1097/NNE.0000000000000215

Recognizing the importance of nursing history, an interdisciplinary team at Appalachian State University created a North Carolina Nursing History Web site (http://nursinghistory.appstate.edu/). The Web site can be used for teaching undergraduate and graduate nursing and other health professions students. One learning activity using the Web site involved the use of the historical timeline. In small groups, students compared historical and political events affecting nursing by decades at the local, state, and national levels. Students identified events that shaped nursing and hypothesized about future events. In a second activity, students viewed the A Century of Caring video and in group format discussed issues related to nursing and historical racial, cultural, and ethnic disparities within the profession. There is a need for other states to digitally archive their own nursing history for the profession and for educational opportunities.

Submitted by: Paul Orkiszewski, MLIS; Phoebe Pollitt, PhD, RN; Andrea A. Leonard, MLIS; Susan Hayes Lane, PhD, RN; Appalachian State University, Boone, NC; lanesh@appstate.edu.

Orkiszewski, P., Pollitt, P.A., Leonard, A.A., \& Lane, S.H. (2015). Using a Nursing History Web Site With Today's Nursing Students. Nurse educator, 40 6, 312. Publisher version of record available at:

https://journals.lww.com/nurseeducatoronline/fulltext/2015/11000/Using_a_Nursing_History_W eb_Site_With_Today_s.14.aspx

Copyright @ 2015 Wolters Kluwer Health, Inc. All rights reserved 